\title{
CD REVIEWS
}

HOLLIGER: Romancendres ${ }^{1}$; Gesänge der Frühe ${ }^{2}$. CLARA SCHUMANN: Three Romances, op. $22^{1}$. ${ }^{1}$ Christoph Richter (vlc), ${ }^{1}$ Dénes Várjon (pno), ${ }^{2}$ Southwest German Radio Vocal Ensemble, Stuttgart, ${ }^{2}$ Southwest German RSO, c. Heinz Holliger. ECM New Series 4763225.

As a composer Heinz Holliger has remained prolific in the ten years since Tempo ran a sixtieth birthday profile. This summer the Lucerne Festival was staging the première of the a-cappella chorus Rosa Loui, as well as Holliger's Three Sketches for violin and viola, a new oboe quartet and recent choral settings of 12 poems by David Rokeah. Meanwhile ECM Records have issued a fine recording of Romancendres, first performed at Lucerne in 2003, and Gesänge der Frühe for choir, orchestra and tape, sub-titled 'nach Schumann and Hölderlin'.

Gesänge der Frühe dates from 1987, and its appearance on disc is particularly welcome. Holliger has described the work as 'almost too personal', but it is this personal element which makes it so fascinating. Like the Two Liszt Transcriptions for orchestra directly preceding it, the four-movement piece enters into a modern dialogue with an artistic idol from the Romantic era. To a certain extent Holliger's Gesänge der Frühe, too, was inspired by a musical source - in this case Schumann's late piano pieces of the same title, op. 133. Schumann himself had thought of incorporating in his title the name of Diotima, the distant beloved of the similarly unhinged Romantic poet Friedrich Hölderlin. Subsequently he dedicated the pieces to Bettina von Arnim, a literary bluestocking who witnessed both Schumann's mental turmoil and that of Hölderlin, half a century earlier.

Holliger's first movement offers a choral version of the first piece from Schumann's op. 133 and the melody of No. 5 in the set. This is married with a spring poem by Hölderlin (not one of the pair Holliger used in his Scardanelli-Zyklus). The movement also incorporates a theme from the F-A-E Sonata (jointly composed in October 1853 for Joseph Joachim by Schumann, Albert Dietrich and the young Brahms) and the recitation of two texts by Bettina von Arnim, the second addressed to Clara Schumann. The second movement features Hölderlin's 'An Elysium' and autopsy reports on the brains of Robert Schumann and Hölderlin respectively. In the next movement Schumann's op. 133 No. 1 reappears on tape, together with Holliger's vocal setting of the 'Diotima' poems. The finale draws on further verses and quotations from Hölderlin. As the work unfolds, the musical referencing multiplies: a choral setting of Schumann's op. 133, No. 5, other reminiscences of that opus and snatches of the Nachtlied op. 108, the melodrama Manfred and the late 'GeisterVariationen'. There's also a chorale ('Wenn mein Stündlein vorhanden ist') that Schumann composed in the sanatorium in Endenich. Some of these ingredients are more covert than others; the above account is indebted to Holliger's biographer Kristina Ericson.

Holliger's ear for expressive sonority was never keener than here. The work begins, pianissimo, on strings and cymbals, using all 12 notes of the chromatic scale. The ending is equally ethereal: following a great climax for the choir and orchestra, a humming chorus of sopranos and altos is underlaid by a vibrating temple-bell. In between, the human voices and instrumental choirs weave music of lyrical richness and depth. Produced in collaboration with Thomas Kessler, the pre-recorded tape includes an out-of-tune piano played by Holliger. According to Roman Brotbeck's booklet note, this recalls a square piano in Hölderlin's Tübingen asylum. Schumann, however, used just such an instrument on which to write his Endenich chorale, thereby reinforcing the biographical associations.

The tape features the actor Bruno Ganz as the voice of Schumann, ${ }^{1}$ Serena Wey as Bettina von Arnim and Michael Maassen as the two forensic examiners. The most arresting effects are those created to evoke a pen's scratching and scraping. Schumann has the last words: 'Nun will ich schließen. Es dunkelt schon' ('I shall close now. It is already getting dark'), from his letter to Joseph Joachim written shortly before his suicide attempt. Almost needless to say, Holliger interprets the remark in a metaphorical sense. But ultimately, for all the verbal play and musical cryptography, his memento mori elicits a ready sympathy for the two artists celebrated here.

\footnotetext{
${ }^{1}$ Ganz (the unforgettable Hitler of Oliver Hirschbiegel's Downfall) long ago recorded a disc of readings from Hölderlin for ECM (New Series 823 643-2, issued 1984). (Ed.)
} 
In 1893 Clara Schumann burned the manuscript of her husband's five Romances for cello and piano, composed 40 years earlier. Brahms approved of the deed, maintaining that Schumann had produced various pieces that were 'hardly worth publishing'. Yet Joachim had responded with great enthusiasm to the copy of the Romanzen he was sent in the month of their completion. Romancendres sets out to atone for what Holliger regards as an act of vandalism. His work is made up of four short movements framed by two miniature funeral marches. A nocturne ('Aurora') with a gorgeous cantabile passage goes before Schumann's derangement, the instruments now simulating wings wildly flapping. The third movement, headed 'The Avenging Angel of the Present', evokes Schumann in sanguine mood - the Florestan mood, one could say. Then an animated exercise in trills picks up on one of the characteristics of the Romances described by Joachim. Other, less prominent devices suggest the aged Clara and Johannes.

Unlike, for example, Elliott Carter in his Cello Sonata of 1948, Heinz Holliger's writing encourages a convergence of cello and piano. These latter-day embers of lost Romances are vigorously stoked by Christoph Richter and Dénes Várjon, who also perform a transcription of Clara Schumann's Three Violin Romances. Should Holliger be minded to pursue this vein of cinder music in some form, then Robert Walser's Aschenbrödel - a companion to the Snow White drama composed by Holliger in 1997-98 - awaits him.

Peter Palmer

RICHARD BARRETT: Opening of the Mouth. ELISION Ensemble. ABC Classics 4763174.

To be blunt: Richard Barrett's Opening of the Mouth is one of the most important compositions of the last 20 years, and this reissued recording is an essential purchase. ${ }^{2}$ The piece was written for ELISION, and few other groups possess the required skills and instrumentarium to attempt a rival release.

Opening's complex construction comprises six overlapping movements (a seventh, an extended electronic prelude played before live performances, is not included on this disc), three of which - Engführung I, Schneebett and Engführung II - con-

\footnotetext{
2 The original release of this recording was reviewed by Robin Freeman in Tempo No. 190 (September 1994), pp. 41-46 under the title 'Richard Barrett, compositeur maudit manqué' (Ed.).
}

tain complete or fragmented versions of solos or duos that may be performed separately (three of these have been recorded by ELISION on NMC D117). A useful diagram in the sleeve-notes helps with orientation.

This overlaying gives Opening considerable polyphonic depth anchored to a strong sense of harmonic and rhythmic coordination, to which ELISION give careful attention. This is established by the first four vibraphone chords of the percussion solo abglanzbeladen/auseinandergeschrieben, which describe a curve as self-contained and clear as any classical cadence, and reinforced by the series of seven tone-centres that shapes the second section. Thus, despite the extravagance of the solo writing, one feels the music strapped to the teeth of a giant machine. This would be a monstrous image were it not for the filigree flourishes that burst between the cracks, tiny moments of human brilliance and resistance, played and recorded here with absolute precision. They might be read as extraordinary products of coalescence, the fleeting potentialities of the system. Their possibility is written deep within Barrett's hypermetrical complexities, waiting to be uncovered and squeezed out.

By the fourth section, Largo, scored for soprano, koto and cello, that depth has been compressed to just three polyphonic lines, each distinctly characterized and now operating within no discernible harmonic or imitative framework. The individual lines - as a result of the music written for them and of the instruments' intrinsic qualities (an inseparable alloy in Barrett's music) - are in one aspect extremely fragile, but at the same time generate enough strength to bear the structural weight of what has gone before and open plenty of doors to future possibilities. There is a dialogue here, or at least a forceful questioning of assumptions, between states and agencies of musical power: great structural weight is placed not upon massed strings or brass, but upon the delicate koto; an instrument that - again contrary to more familiar orchestral tropes - is generally heard by Western ears as ornamental exoticism.

The reduction of rhetorical flair continues still further in Schneebett. The most remote and selfeffacing of the movements so far, it functions as the ultimate collapse or landing of the denser structures that have preceded it. This withdrawal is also a slow penetration, as though the listener is being led through a series of curtains into a silent inner sanctuary or operating theatre. The resonant acoustic in which this CD has been recorded is important: it allows the sounds to drip with moisture, giving a sense of space inhabited. Out of this still centre erupts Zungenentwurzeln, the only sec- 
tion composed entirely for electronics. Barrett's sounds, however, all squelches, rasps and running fluid, have an organic texture that encourages the ear not to contrast electronic with acoustic, but to reflect on certain physical, fleshy continuities in the creation and reception of sounds themselves.

When human agency returns, in the long Engführung II movement, it is both unmediated (mezzo-soprano) and mediated (percussion, electric guitar, sampler). The potential suggested in Zungenentwurzeln is passed once more to the unpredictable interactions of lips, fingers, mouthpiece, keys, wood and strings; sections of the score - until now obsessively detailed - give way to guided improvisation, another string on ELISION’s bow.

These interactions extend beyond the physical act of producing a sound. A clarinet solo acts upon a voice, a vibraphone stretches voices and electronics taut. The musical objects - solos and chamber works each with independent lives of their own - interact as human beings do, sometimes passive, sometimes active. We recall the breath and sinew that is music making, and that the interactions recorded here are both symbolically and actually interactions between human beings. The musicians of ELISION are not only theatrical representations of human adventure and endurance, they are also doing it for real.

I don't mean to suggest here any sort of programme. In spite of localized consistencies, Barrett's music works constantly to undo expectations and pattern recognition. What audible structure there is in Engführung II derives from fragmented versions of solo works for clarinet, violin and cello, shuffled together and augmented with parts from elsewhere in the ensemble. Although there are carefully arranged continuities that maintain the movement's coherence, the sorts of assertions that are necessary for narrating a programme are impossible. To talk in such terms is to grant the music certainties - of characterization, scenario, conflict and resolution - that it manifestly avoids on every audible level. ELISION's recording of Opening of the Mouth doesn't present a model of humanity, but draws out some of its expressive potential from threatening and darkened surroundings; its touch upon our own skin and eardrums is miraculous. We emerge at the end coated in grime and glistening sweat.

Tim Rutherford-Johnson
Figments and Fragments: Chamber Music by ELLIOTT CARTER. Sonata for Cello and Piano; Figments 1 and 2; Enchanted Preludes; Scrivo in Vento; Gra; Con Leggerezza Pensosa; Fragments 1 and 2; Elegy for String Quartet. Johannes Martens Ensemble: Johannes Martens, Joachim Kjelsaas Kwetzinsky, Tom Ottar Andreassen, Andjei Maevski, Anders Nilsson, Yi Yang, Anders Rensvik. 2L 2L54SACD.

ELLIOTT CARTER: $100^{\text {th }}$ Anniversary Release. Mosaic; Scrivo in Vento; Gra, Enchanted Preludes; Steep Steps; Figments 1 and 2; Riconoscenza per Goffredo Petrassi; Rhapsodic Musings; Dialogues. New Music Concerts Ensemble dir. Robert Aitken: Robert Aitken, Max Christie, Virgil Blackwell, David Hetherington, Fujiko Imajishi. Naxos 8.559614 with DVD 2.110256.

Both these discs were intended as part of the widespread celebration of the Carter Centennial, the second more explicitly so, and they offer (with a certain amount of overlap between the two discs) a crop of relatively recent smaller pieces for solo instruments or small ensembles anchored by larger and more substantial works. Carter's smaller-scaled works started in the 1980s as a trickle amidst much larger pieces, and have become increasingly more prevalent over the years, mostly as birthday and memorial tributes to friends - often composers - but also as works for the world-class performers who have championed Carter's music.

The music of composers who survive into old age and continue to write usually undergoes some sort of qualitative change. Although the dimensions of his works remained more or less the same, in his old age Verdi turned to comedy for the first time in his mature career. Vaughan Williams's later works were suddenly brimming with new and vivid instrumental color, allied with an expanded tonal and harmonic sense. The music of Stravinsky's last period, aside from being 12-tone, displayed a greatly increased concentration and compression of substance, texture, and time-scale. (Although there is probably not much else that they have in common, both Vaughan Williams and Stravinsky, in their last major scores - the Ninth Symphony and Requiem Canticles, respectively - produced works of summation that seem to be continually referencing their earlier music.) Virgil Thomson, reflecting an older person's reluctance to spend too much time by himself or to expend too much stamina at a time, returned to an earlier practice of writing musical portraits of people who would sit in a room with him for an hour at a time. Arthur Berger, having conceded that the world at large wasn't particular- 
ly interested in music, stopped writing new music; although, being unwilling to completely give up on composition, he began to re-write his pieces, but recasting and altering them so they became virtually new works. Strauss, Fauré, and Brahms also offer striking examples of stylistic changes in the last stages of their careers.

Carter's later career has been marked not only by an increase in shorter, smaller-scaled works but also, generally, by a change in both the density of the music and the scope and complexity of the initial generating idea and its development. (The Sinfonia: sum fluxae pretium spei, Carter's longest single work, from 1996, is in some ways an exception to this trend, and in others not.) Whereas in an earlier phase Carter would say,

I've lots of ideas about writing for the orchestra and do like to have time and the incentive to put them down, but it's a terrible lot of thought, imaginative effort and just plain note writing. I limit myself to a small number of orchestral pieces ...

by the mid 1980s, his attitude was,

I am continually thinking of musical possibilities, of short motivic figures, chord progressions, trying over in my head all sort of musical textures and colors. Sometimes one of these seems particularly interesting, and then I begin to think how it could be led into and away from, and soon a whole section of a piece begins to form itself ... with each piece I try to do something different because I like to be involved in the piece and take chances with it, not knowing at first where it will lead or how it will turn out. To me, it's like going on an expedition to a place where I have not been. ${ }^{3}$

These shorter works, displaying a staggering profusion of materials, expressive characters, instrumental textures, narrative strategies, and musical realizations are evidence of a vivid musical imagination, worthy of comparison with that of Haydn. The solo works, Scrivo in Vento, Gra, Figments I and II, Steep Steps, Riconoscenza per Goffredo Petrassi, and Rhapsodic Musings all have in common their presentation of clearly delineated contrasting materials whose interactions, either cooperative or confrontational, or both in turn, are the substance of the formal trajectory of the work.

The Cello Sonata (1947-48), which is the major piece on the Johannes Martens Ensemble disc and the oldest work on either disc, was, along with

\footnotetext{
3 Both of these quotations, the first from a 1973 interview with Stuart Liebman in the Boston Phoenix, and the second from an interview at the Banff Center with Robert Johnston, Michael Century, Robert J. Rosen, and Don Stein in 1984, are contained in Elliott Carter: A Centennial Portrait in Letters and Documents, edited by Felix Meyer and Anne C. Schreffler (Woodbridge, Suffolk: The Boydell Press, 2008.), pp. 213 and 257, respectively.
}

the Piano Sonata of two years earlier, the harbinger of what one might call Carter's mature style, which conclusively arrived with the First String Quartet in 1951. The beginning idea of the Sonata is that the manner of sound production of the two instruments is irreconcilable and that those differences should be featured rather than hidden. This idea, which is at the same time abstract and completely grounded in a simple aural reality, leads to the development of distinct thematic material and the projection of different senses of the movement of time for the two instruments, and thus generates a continuously unfolding, intensely dramatic form that eventually comes full circle, but with those instrumental characteristics and materials reversed. Enchanted Preludes of 1988 starts with an idea both similar and contrary to that of the sonata: the two instruments, a wind and a string, mimic each other's characteristic sonic and articulative qualities, creating a continuously-fused airy textural web while maintaining separate and distinctive intervallic and rhythmic vocabularies. Con Leggerezza Pensosa, for clarinet, violin, and cello - whose title, drawn from the writings of its dedicatee, Italo Calvino, which means "lightness of thoughtfulness', might serve as a description of the manner of all these later pieces - also builds its form from the differentiated sonic, rhythmic, and intervallic characteristics of the three instruments, but in this case treating them as parts of a larger meta-instrument which subsumes them all, the form being the dramatic curve of their fusions and oppositions. Fragments I and II (1994 and 1999, respectively) and the Elegy of 1946 are brief textural essays which stand as pendants to the five string quartets which, as a unit, stand as a major component of Carter's output.

The major works on the New Music Concerts Ensemble disc are Mosaic (2005) for harp and seven instruments and Dialogues (2004) for piano and 18 instruments. Mosaic, which is a tribute to Carlos Salzedo, harpist and composer, who was one of the ultramodernists composers who were influential on Carter during his early years, explores many of the innovative harp-playing techniques developed by Salzedo through a series of short episodes described by Carter as being like tesserae (the individual stones making up a mosaic.) Dialogues is the first of three late works (the others being Soundings of 2005 and Interventions of 2007) exploring the conversational and sometimes confrontational relationship between solo piano and a large instrumental ensemble.

Although all of the performances on both discs are, to say the least, completely above reproach, the most memorable is that of the Cello Sonata by Johannes Martens and Joachim Kjelsaas 
Kwetzinsky. Searingly passionate, powerfully intense, completely in control of the technical and rhythmic difficulties and the musical and expressive complexities of the work, while always beautiful of sound, it seems to me to be the best performance of it, either live or on recording, that I have experienced. In general the lingering impression of the performances of the Johannes Martens ensemble is of the strongly vivid instrumental color of their performances (in the case of the early gentle Elegy, perhaps to its detriment), but the performances of the members of the New Music Concerts Ensemble are also uniformly strongly expressive and musically satisfying. The contrasts between the more playful performance of Gra by Andjei Maevski and the more aggressive one of Max Christie, Robert Aitkens's intense and sensuous performance of Scivo In Vento and Tom Ottar Andreassen's rather cooler one, are interesting to think about, and between them offer one a fuller picture of the respective pieces.

The Naxos disc comes with a DVD documentary entitled Elliott Carter in Toronto in 2006, which contains a conversation between Carter and Robert Aitken and performances of Mosaic and Dialogues.

Rodney Lister

THOMAS WILSON: Cancion; Three Pieces for guitar ${ }^{1}$; Piano Sonata ${ }^{2}$; Piano Trio ${ }^{2,3}$; String Quartet No. $3^{3}$; Incunabula ${ }^{2} .{ }^{1}$ Allan Neave (gtr), ${ }^{2}$ Simon Smith (pno), ${ }^{3}$ Edinburgh Quartet. Delphian DCD34079.

This new Delphian release provides a very welcome, generous representation of Thomas Wilson's chamber and instrumental works. Born in the USA, but a Glasgow resident for most of his life, he was a contemporary of Iain Hamilton and Thea Musgrave and a leading member of a group of composers, including William Wordsworth, John Maxwell Geddes, Robert Crawford, David Dorward and Shaun Dillon, who helped to achieve a renaissance of music in Scotland in the latter half of the 20th century. Wilson's music is lucid, disciplined, illuminated by a burning integrity, and largely untouched by transient musical fashions, though occasional use is made of aleatory technique and electronic music. It is predominantly serious in tone (although there are notable exceptions, including Touchstone (1967), a humorous orchestral portrait of the clown in Shakespeare's As You Like It) and frequently atonal, but with an almost classical concern with form and proportion.
The earliest piece on the disc, the Third String Quartet of 1958, is a key work and something of a watershed for the composer as he suppressed most of his predominantly tonal compositions written before it. It won him the McEwen Composition Prize in 1959 and marked a move to a more chromatic and dissonant style. The opening Allegro agitato begins with a statement of the four-note motif from which the material of the whole work is derived. The eloquent second subject presents genuinely purposeful dialogue between all four voices and this sense of intimate discourse is maintained in the Lento central movement, with its mainly fugal unfolding. In the central episode of the finale, Wilson suspends development of the initial ideas to interpose a fugal-style scherzo. This finely-wrought piece receives a deeply satisfying performance from the Edinburgh Quartet, who recorded the composer's Fourth String Quartet (1978) for Meridian Records in 2001.

Wilson's Piano Sonata was originally written in 1959, then set aside and revised in 1964. Like Beethoven's final contribution to the genre, it is in two movements, of which the second is a set of wide-ranging variations. Characteristically, the Adagio introduction to the first movement contains the germinal ideas of the whole work, including the key interval of a tritone. An increase in tempo to Allegro potente signals the arrival of the main body of the movement, which contrasts steely, vigorously dramatic material with a calmer, but more unsettled second subject. The slow movement's seven linked variations are strongly contrasting and include a puckish scherzo. Simon Smith responds magnificently to the considerable technical challenges of the opening movement and proceeds to bring out the individual character of each variation.

The one-movement piano trio (1966) falls into seven clearly defined sections, of which the first provides an extended dialogue for strings and piano alternately and the second is a dynamic Allegro in which the instruments are heard together for the first time. The third part, a cadenza for solo cello, leads to the fourth, a scherzo in which all the instruments again take part. The fifth section is a cadenza for solo violin, while the sixth is a lyrical elegiac movement which ultimately leads to a coda, in which the music of the opening is briefly revisited before the work comes to a hushed conclusion. Whereas the sonata's key interval was a tritone, it is Shostakovich's musical signature of $\mathrm{D}-\mathrm{S}-\mathrm{C}-\mathrm{H}$ which haunts the Piano Trio. Pianist Simon Smith with Tristan Gurney and Mark Bailey of the Edinburgh Quartet do full justice to both the intensity and the lyricism of this searching piece. 
Wilson frequently used one composition as a springboard to a subsequent work: the solo piano piece Incunabula (1983) originated in the piano part of a cycle of seven 'songs from the Chinese', The Willow Branches, and in turn furnished material for the Piano Concerto (1984), written for David Wilde. The title might be freely translated as 'getting back to basics' and it represented an element of re-thinking by the composer of some of the possibilities of musical form. It consists of an unfolding series of developing musical ideas or prisms, which are subtly connected. A haunting piece, it is substantial enough to be regarded as a single-movement sonata, though perhaps Wilson considered its evolution too instinctive and its structure too fluid to qualify for that genre. It takes in an introductory fantasy, a scherzo, a dark nocturne and ends in an extended ethereal Molto Adagio section which gradually fades away. Simon Smith has the measure of its elusive, occasionally hallucinatory character.

The two short works for solo guitar are notable for their naturally idiomatic writing for the instrument (a concerto followed in 1996). The Three Pieces for guitar, which date from 1961, are based on a 12-note series and vividly expressionist in tone; they consist of a scherzando-like moto perpetuo, a lyrical Lento and a rhapsodic Moderato. The later Cancion (1977) has a freely improvisatory quality, almost song-like in its spontaneous eloquence. Both works are sensitively and imaginatively rendered by Allan Neave.

Delphian are to be warmly congratulated for bringing these tough but elegant, closely argued and well crafted works to a wider public with superbly committed performances in vivid recordings. Astonishingly, this is the first $\mathrm{CD}$ devoted entirely to Wilson's music since a Chandos disc containing his Piano Concerto and Introit appeared over 20 years ago. It is to be hoped that record companies will lose no time in seeking out more of his music, including such impressive large-scale works as the one-act radio opera The Charcoal Burner (1968), the Missa pro Mundo Conturbato (1970), the Sequentiae Passionis (1971) for chorus and orchestra, the three-act opera The Confessions of a Justified Sinner (1974) commissioned by Scottish Opera, the Viola Concerto (1987), the Fourth Symphony, subtitled Passeleth Tapestry (1988), the Violin Concerto (1993) and the Fifth Symphony (1998), the composer's last major piece before his death, at the age of 73, in 2001.

Paul Conway
'UBS Soundscapes: Pioneers'. Music by LUKE BEDFORD, JOE DUDDELL, MARTIN SUCKLING, JASON YARDE, HELEN GRIME. London Symphony Orchestra c. Francois Xavier Roth. LSO LSO5032.

Colin Matthews is artistic director of the UBS Artistic Pioneers Scheme. The chosen pieces are workshopped with the LSO and then performed live at the Barbican, London. In a seven-minute recorded 'Introduction' headed by Colin Matthews, the violinist Sarah Quinn reveals her excitement as to the newness of the experience; the conductor Francois Xavier Roth comments, too, as do featured artists. Pierre Boulez adds his comments - unsurprisingly perhaps, his advice is to 'go further, go further'.

Luke Bedford's 2006 piece Outblaze the Sky was inspired by D. M. Thomas's novel 'The White Hotel', in particular by the dreamy poem near the start of the book. It is short ( $\left.5^{\prime} 23^{\prime \prime}\right)$ - something which, to the composer, meant monothematicism. Even in this small frame, however, there is a feeling of inevitable growth from the hazy opening (a direct response to the poem) to the final outing of the sky's blaze.

Joe Duddell has been influenced by bands such as Radiohead and New Order. His Azalea Fragments (after Patrick Heron) is the composer's tribute to the eponymous painter and is a reaction to the painting 'Azalea Gardens' at the Tate at St. Ives. It depicts, clearly, the emotions felt on seeing the blaze of colour for the first time. Duddell's language can be clearly based in the music of the English Conservatives, but is not limited to them.

In contrast to the near-Impressionist atmospherics of Duddell comes the clear high jinks of Martin Suckling's The Moon, The Moon (2007). The composer's stated intention was to write something that 'felt like an overture' and, in its bright colours and passages of held-breath expectancy, it succeeds. There is a light orchestrational touch that could almost be described as post-Mendelssohnian, and if Edward Lear's Owl and the Pussycat is the stated referand, the spirit of Shakespeare's Midsummer Night's Dream is also invoked.

Jason Yarde's Rude Awakening (2006) is an attempt to capture an event that actually could happen within three minutes. The piece moves from the comfort of early morning to alarum (alarm clock) and the panic of only having two minutes to be where you need to be. Yarde comes from a jazz background, both as performer and composer, and one can hear this in the syncopations. This is his first piece for full symphony orchestra. 
Finally, Helen Grime's Virga. Virga is precipitation that falls from a cloud but evaporates before it hits the ground, illustrated here in falling cascades of sound. There is a distinctly lyrical bent at work, with long, expressive string melodies that show no inclination to end set against the more active movement elsewhere.

Francois Xavier Roth won the Donatella Flick Conducting competition in 2000 and was the LSO's assistant conductor for two years. His direction is sure, and his ear for subtle textures (as in the Duddell, for example) reveals a subtle ear for sonority. A fascinating release.

Colin Clarke

ARTHUR BUTTERWORTH: Symphony No. $1^{1}$; Symphony No. 42; Viola Concerto ${ }^{2,3}$. ${ }^{3}$ Sarah-Jane Bradley (vla), ${ }^{2}$ Royal Scottish National Orchestra c. Arthur Butterworth, ${ }^{1}$ Hallé Orchestra c. Sir John Barbirolli. Plus talk by the composer. Dutton Epoch CDLX 7212 (2 CD-set for the price of one).

We are now being regularly treated to additions to Dutton's British music series, and this one is another absolute triumph. It is immensely gratifying to see real attention being devoted to Arthur Butterworth (b. 1923), who continues to make such a unique and immeasurable contribution to British symphonic literature. His Symphony No. 4 (1986) is a swirling, Heathcliffian landscape of long, dark swathes of Pennine moorland under wintry skies. The epic grandeur of Butterworth's orchestral canvases are counterbalanced by an intensely emotional inner language: as with his idol Sibelius, this language finds voice in long and expressive lyrical passages where the different orchestral divisions are deployed with great skill and clarity. Listen to the long, slow third movement (echoes of Tapiola and Pelleas and Melisande) and you will hear what I mean. Everything sounds right, and the intensity is often at its greatest when solo instruments (often violin and oboe, but maybe a clarinet, or even a brace of clarinets) are cast in dialogue with one another, sometimes underscored by a shimmering, tritonic harp arpeggio. We are privileged to have the composer conducting his own music: what 85 -year-old could match the clarity of focus and brilliance of attack and dramatic energy he brings to this recording? The commitment is total and never flags for a moment of its 43 minutes. We are also fortunate in having Butterworth's own sleeve notes.

Every bit as impressive and equally grand in scale is the Viola Concerto op. 82 (1992), also playing at nearly 40 minutes. (Butterworth has also completed a Cello Concerto and a Violin Concerto, the latter broadcast by Nigel Kennedy.) The Viola Concerto is another wondrous addition to the repertoire (which is hardly large) and is in a more serene and intimate vein than the Symphony. The opening clarion horn calls palely recall Vaughan Williams Fifth Symphony and the music follows long, poetic lines: the viola's sultry tone weaving and plaiting threads of restrained love and subdued longing. A beautiful extended cadenza asks many questions to which the orchestra gradually assembles its muted and ambiguous responses.

If Symphony No. 4 is 'Wuthering Heights', Symphony No. 1 is 'Rain, Steam, and Speed'. The very stormy first movement cites references to Sibelius's Sixth Symphony. The influence is acknowledged by the composer in his interesting 27-minute talk which concludes the first disc, in which he discusses his early life, war service and other formative personalities, including Vaughan Williams and Barbirolli. Butterworth describes how the piece was begun in the late 1940s and emerged gradually over the succeeding seven years. The final movement's structure was inspired by the moto perpetuo concept of a chamber work by Leonard Salzedo. The recording we are presented with here is the remastered version of Barbirolli's own live performance at the 1958 Proms, the year after he conducted the work's first performance. Be prepared for a rather rugged sound quality: Barbirolli's 34-minute reading compares interestingly with Douglas Bostock's 40 minutes for the Classico label made a few years ago (CLASSCD 274). This was Butterworth's first really important piece and we are lucky this rare document has survived. The Hallé are clearly in full assimilation of the Butterworth idiom and even if clarity of detail is sometimes a bit hard to come by, the dark atmosphere of this live broadcast is as insistent and compelling as the sudden shafts of light which eerily brighten the landscape.

This is a most generous helping of rich treasure. The next instalment with the recent Fifth Symphony (2003 - Butterworth has recently completed a Sixth) and a number of shorter orchestral pieces is very keenly awaited. Many of Butterworth's 130 or so works will also be discussed in a forthcoming book about him by my fellow contributor Paul Conway. This release is an absolute must. The usual very high production and engineering standards apply.

Bret Johnson 
SIMON MAWHINNEY: Batu ${ }^{1}$; Barcode III $^{2}$; Hunshigo ${ }^{1,2}$ ${ }^{1}$ Mary Dullea (pf), ${ }^{2}$ Darrah Morgan (vln). Altarus AIRCD-9027.

In his informative CD notes, the Northern Irish composer Simon Mawhinney (b. 1976) states that 'What interests me is what Morton Feldman called the "abstract experience". Music takes us on a journey. In writing music I want to travel as far as possible. Compositions are like postcards'. Mawhinney's travelling companions on this disc are the pianist Mary Dullea and violinist Darrah Morgan; Morgan's lectures on extended technique led to Barcode III, and the remaining works on the disc were written for the respective performers.

Hunshigo was originally intended as a tenminute lyrical vehicle for Morgan and Dullea: the end result was some 45 minutes long. Unlike the other two works on the disc, virtuosity is not foregrounded (although it clearly is required). Rather, it consists of a series of broad paragraphs, often lyrical and evocative, in which sounds are allowed to run their own course. Sustaining a meditation of this nature for three-quarters of an hour is no simple matter, for both performer and listener. Certainly, there are arresting and beautiful moments, and the individual sections hold one's attention, but I found it impossible to grasp the work's dimensions as a whole. In its depth and level of detail, this is more of a traveller's guide than a postcard, and as such offers a host of interesting areas to explore.

The remaining works are shorter and more direct. Barcode III for violin explores virtuosity and extended techniques, not least through Mawhinney's interest in Middle Eastern music. A variety of contrasting ideas, often in dialogue, help accumulate energy leading to a climax. Inspired by the experience of climbing hundreds of steps to a Hindu Shrine in Kuala Lumpur, the first work on the disc, Batu for solo piano, starts off with skittish, rapid figuration over long-sustained bass notes. The pianist is required to play much of this figuration with a light touch that can result in certain notes failing to sound. As the work progresses, material appears in a more moderate tempo; the superimposition of different apparent tempi gives the work a sense of space and grandeur. Somehow the pianist Mary Dullea finds extra fingers to play increasingly florid arabesques, creating washes of sound that get increasingly ecstatic as the work builds to an elaborate and sonorous climax. The hushed ending questions the nature of the experience, though one is left in no doubt about the seriousness of Mawhinney's art.

Edward Venn
GÓRECKI: 'Life Journey'. Requiem Für Eine Polka for Piano and 13 Instruments; Valentine Piece for solo Flute and little bell; Two Sacred Songs; Toccata for 2 Pianos; Variations For Violin and Piano; Four Preludes For Piano; Three Songs; Concerto for 5 Instruments and String Quartet. Chamber Domaine. Landor LAN287 (www.LandorRecords.co.uk)

Since its formation in 1999, Chamber Domaine has eagerly pursued a thought-provoking project entitled 'Music of Our Time', linking art, poetry and architecture with 20th- and 21st-century music, in many concerts and workshops throughout the United Kingdom, Europe and North America. Following this audacious ensemble's Wigmore and South Bank Centre debuts, it has performed numerous premières of works by well-known composers and now, with positive encouragement from the innovative new music label of Landor Records - pursuing a parallel contemporary trend - they have together celebrated the 75th birthday of one of the world's most admired living composers, Henryk Górecki. Performers and record company have combined eloquently to create a new recording named Life Journey, covering an imaginative selection of his music, ranging from intimate, lesser-known, pieces of his student days, to more recent works for larger ensemble -including several world première recordings.

Ever since the unique presentation of his highly renowned Third Symphony, Symphony of Sorrowful Songs, when Dawn Upshaw linked with the London Sinfonietta, selling over one million copies of that profound tour de force, Górecki has composed much music that has rarely been heard. On this new recording, 17 soloists, including strings, brass, woodwind, percussion, 2 pianists and mandolin, communicate a charismatic assortment of works that possess immense style and character, ranging from the poignant Two Sacred Songs, for piano and baritone, to the riveting Requiem für Eine Polka for piano and 13 instruments.

Soon after Stephen de Pledge and Ronan Collett (baritone) present an intense account of his Two Sacred Songs, Chamber Domaine rekindle an earlier example of Górecki's energetic muscularity, as Stephen combines with Evelina Puzaite to present the Toccata For Two Pianos, with compelling dynamism. The immense diversity of his musical style is even further emphasized when, following the solemnity of Three Songs - dedicated to his mother - Chamber Domaine enters another vibrant sound-world. Although commencing with highly meditative piano, surrounded by 13 other instruments, including bells, the unique Requiem Für Eine Polka subsequently 
transposes into a much more extravert mode in its third movement, when a pulsating combination of instruments, dominated by brass and wind, almost evokes the mind-blowing rhythmic eccentricity of Khachaturian's ballet suite Gayaneh .

The contemplative earlier moments of the Concerto for 5 Instruments and String Quartet portray a shadowy 12-note flavour - with indistinct echoes of Schoenberg and Webern - leading on to a more rhythmic conclusion, containing dynamic energy and supreme invention, all of which is expressed with devoted skill and artistic enthusiasm. Chamber Domaine has, once again, combined intense virtuosity, quiet contemplation and passion in a series of cutting-edge performances on this new recording, bringing its name sharply to the forefront of modern musical ensembles - much akin to London Sinfonietta, in 1992.

John Wheatley

BEAT FURRER: Piano Concerto ${ }^{1}$; invocation $V^{2}$; Spur $^{3}$; FAMA VI ; retour an dich ${ }^{5}$; Iotófagos ${ }^{\text {I }}{ }^{1}$ Nicholas Hodges (pno), ${ }^{1}$ WDR Symphony Orchestra Cologne c. Peter Rundel, ${ }^{2}$ Petra Hoffmann, ${ }^{6}$ Tora Augestad (sops), ${ }^{4}$ Isabelle Menke (voice), Eva Furrer $\left({ }^{2}\right.$ bass fl, ${ }^{4}$ contrabass fl), ${ }^{6}$ Uli Fussenegger (db), ${ }^{3,5}$ Kammerensemble Neue Musik Berlin. KAIROS 0012842KAI

Beat Furrer (born 1954) studied composition with Haubenstock-Ramati in Vienna; he also founded Klangforum Wien. His Piano Concerto is a work that searches for new directions in sound. Furrer states that he is concerned with 'maintaining the plasticity of the piano sound'. The piano itself is the 'centre of gravity', while the orchestra amplifies around it. Furrer initially concentrates on the lower register of the piano, and experiments with silently fingering low notes and activating them via higher registers (presumably inspired by Schoenberg's op. 11). On a pitch/timbral level, the work moves progressively towards the higher registers, in the process sounding increasingly metallic. In the centre of this journey lies a central slow haven.

Nicolas Hodges, along with Rolf Hind and Ian Pace, has long held a special place in the performance of contemporary piano music. His contribution is superbly assured. The concerto dissolves upwards rather than ends per se, and out of the crystal sound of the piano's extreme upper register emerges Petra Hoffmann's high soprano intertwining with Eva Furrer's contrabass flute in invocation VI. This is the sixth scene of Furrer's invocation, an opera based on Margaret Duras's novel moderato cantabile that begins with the interruption of a child's piano lesson by screams of death. Hoffmann's control is breathtaking. Furrer takes a text by Juan de la Cruz, an invocation of Christ as Bridgeroom to the Soul, exploring multiple meanings of the text, from yearning to rapture and torment.

Spur ('pathway', 1998) for string quartet and piano, layers repeated patterns to give an impression of constant - although not unstoppable - motion. As with the Piano Concerto, the piece progresses upwards in pitch as it unfolds; strings, also, are increasingly foregrounded. Furrer plays with the created forward motion, interrupting it unexpectedly, forcing it to flow around the caesurae. The performance is outstanding.

Marie Luise Maintz's booklet note, 'Physiognomy of the Scream', traces the importance of the scream as an 'extreme dimension of expressivity'; also, as a prelingual sound, it reflects Furrer's interest in the boundary area between language and music. Scream is most evident at the opening of the 2005 theatre piece FAMA, based on Arthur Schnitzler's Fräulein Elsa, which begins with collective screaming (Kairos 0012562KAI). What is offered here is the sixth scene, for voice and bass flute, a scene underpinned by the protagonist's fear. The disjunct expression, frequently whispered, is counterpointed by the flute's reactions. The 1984 piano trio retour an mich includes an instrumental scream (fff tone clusters in the middle section). Furrer composes in a spiral form, circling round an imaginary centre. The glassy sounds of the concerto recur in the frozen, frigid exchanges of thirds between strings and piano at the work's centre.

Lotófagos means 'Lotus eater' and refers to Odysseus' companions who ate lotus to forget. Furrer plays with the concept of memory. The scoring might imply registral space (and indeed this is exploited), but the fascinating sound of double-bass harmonics against solo voice actually puts the two soloists in the same register, interacting, as a prime gesture.

Colin Clarke

SOFIA GUBAIDULINA: Complete works for solo piano. Marcela Roggeri (pno). Transart TR161.

JOSEP CERCós: Obra Pianistica. Emili Blasco (pno). Edicions Albert Moraleda 0196.

Sofia Gubaidulina's piano music dates from the 1960s and early 1970s; as such it predates the 
music by which she came to be known in the West. The exploration of the timbral potentials of the piano and the expressive effect caused by the juxtaposition of contrasting styles and modes of organization in these works offer early examples of some characteristics that define Gubaidulina's later output.

The first and last works to be included on the disc utilize Bach as a reference point. The Chaconne (1963) draws on the Baroque form as a vehicle to bring together a range of styles and dramatic gestures. This polystylism should not be read into too deeply in the light of the composer's subsequent output: rather, it gives access to diverse characters that help shape the discourse. Allusions to Bach, such as in the rich organ-like texture of the Chaconne theme, also carry with them a sense of spirituality that is so important to Gubaidulina's music. The final work, the Invention of 1974, is a homage to Bach's two-part inventions.

The Sonata (1965) extends the range of sonorities available, not only through clever pedal effects but also through playing inside the body of the instrument. Once again, distinct textures, sonorities and modes of organization are juxtaposed to create a compelling structure that, despite its apparent freedom, nevertheless engages the listener and carries the music forward.

The series of character pieces in Musical Toys (1969) are by turn humorous, evocative and delightful; similar to Schumann's Kinderscenen, this is music for children that adults can appreciate. As with the Piano Sonata, the use of the pedal and holding down keys widens the palette of sounds and offers a greater range of expressive effects. Similar instances can be found in the small-scale Toccata-Troncata (yet another Bachian allusion?).

In these live performances, the pianist Marcela Roggeri demonstrates an engaging deftness of touch that allows these works to speak clearly with wit, charm and passion.

The other disc includes three works for piano by the Catalan composer and pianist Josep Cercós Fransi (1925-1989). According to the CD notes, Cercós's compositional output moved through four distinct stages: initially 'post-romantic', he turned to a neo-classical idiom, then work 'characterized by constant investigation and innovation' that was stimulated by his encounter with the European avant-garde, and finally a late period that synthesizes the earlier three. Although the works on offer belong chronologically to each of the final three periods, they each demonstrate certain idiosyncrasies that suggest the disc might not be wholly representative of Cercós's achievements.
The first piece, a Hindemith-inspired Sonata en si m (1952), belongs to Cercós's neo-classical phase. An earnest sonata-Allegro establishes many of the main characteristics to be found in all four movements: a straight-forward formal scheme, harmonic clarity, some interesting rhythmic quirks, a tendency for contrapuntal writing and lighter textures, and a generally understated character that avoids grand climaxes. This seeming refusal to commit to bold gestures lessens the effect of the motoric rhythms of the Scherzo and Trio and inhibits the lengthier slow movement. A lighter finale closes the sonata. The work as a whole ultimately failed to please Cercós, who tried to destroy all copies; a 1954 publication of it prevented it from being lost.

Composed during Cercós's more experimental phase, La utilitat de les flors (1967) nevertheless adopts a straightforward traditional approach that befits its function (a children's ballet); the disc therefore contains no example of the composer's avant-garde work. The seven movements are all short character pieces, often gently witty, and the set frequently alludes to other composers and a range of genres. As with the sonata, dramatic and climactic moments are suppressed or avoided in favour of elegance.

The final work, Escenes d'un Circ (1980) is another short ballet for piano, again with seven movements, and again preferring a story that avoids the need for the flamboyance or high emotion. Once again, character pieces are the order of the day, and traces of the composer's late period, or synthesis of different styles, are absent. Perhaps it is the case that Cercós's output as a whole is marked by a quiet, unassuming voice that prefers pastiche, charm and subtlety to grander gestures. If so, this disc provides a suitable, if unremarkable, introduction. Nevertheless, a disc that includes two pieces that have little connexion to the composer's main concerns at the time (the ballets) and one that he wished to destroy, offers first-time listeners a curious means of approaching this unfamiliar body of work.

Edward Venn

CORIGliANO: Circus Maximus (Symphony No. 3 for large wind ensemble); Gazebo Dances. University of Texas Wind Ensemble c. Jerry Junkin. Naxos American Classics 8.559601.

JONES: Symphony No. 3, Palo Duro Canyon; Tuba Concerto. Christopher Olka (tba), Seattle Symphony c. Gerard Schwarz. Naxos American Classics 8.559378. 
GIANNINI: Piano Concerto; Symphony No. 4. Gabriela Imreh (pno), Bournemouth Symphony Orchestra c. Daniel Spalding. Naxos American Classics 8.559352.

SCHULLER: Variants for Jazz Quartet and Orchestra; Journey into Jazz; Concertino for Jazz Quartet and Orchestra. Boston Modern Orchestra Project c. Gil Rose. BMOP 1004.

DAUGHERTY: Sunset Strip; WILLIAMS: Escapades for alto saxophone and orchestra ${ }^{1}$; ROREM: Lions $^{2}$; ROUSE: Friandises. ${ }^{1}$ Branford Marsalis (alto sax), ${ }^{2}$ Branford Marsalis Quartet, North Carolina Symphony c. Grant Llewellyn. BIS-SACD-1644.

'Abraham Lincoln Portraits'. IVES: Lincoln, the Great Commoner. PERSICHETTI: A Lincoln Address. HARRIS: Abraham Lincoln Walks at Midnight. BACON: Ford's Theatre. GOULD: Lincoln Legend. McKAY: To a Liberator. TUROK: Variations on an American Song. COPLAND: Lincoln Portrait. Soloists, Nashville Symphony Chorus, Nashville Symphony c. Leonard Slatkin. Naxos American Classics 8.559373-4 (2-CD set).

The Circus Maximus was of course the venue for the Greatest Show on Earth at one time. John Corigliano has suited the music to fit the action, in his most explosive and visceral manner. It isn't just roaring lions, careering chariots and screaming humans however. It's much worse than that. All repulsive human folly is here ... cruelty, vulgarity, and obscenity. Does the composer wallow in it? No, he translates it into a contemporary context where voyeurism has returned and mass entertainment now takes the form of reality TV, celebrity culture and the internet. The only missing ingredient from this modern-day paradigm is death. The sound quality is magnificent and the CD concludes with the early Gazebo Dances (1972). Corigliano has just opened a spectacular new website: www.johncorigliano.com.

The Mississippian Samuel Jones (b. 1935) turns to the grandeur of the southwestern USA in his Symphony No. 3, Palo Duro Canyon, named for a notable landmark not far from the town of Amarillo. A quiet start quickly yields to animated brass fanfares which put me in mind of Menotti's Apocalypse and the final movement of Rautavaara's Eighth Symphony (written some years later!). There are other similarities to Rautavaara in the harmonic structure and multi-layered lyricism. But that Jones is a skilled and original craftsman is also evident from the Tuba Concerto (2005). This is his second Naxos recording, but with a number of other Seattle Symphony commissions to his credit in recent years I hope it won't be his last. Vittorio Giannini's music belongs to a much earlier aesthetic. The massive Piano Concerto (1937) hasn't been heard for 70 years. It may have struck some familiar chords at its première but today it exudes a warm Romantic afterglow. It may be derivative at times, but its confident stride carries all before it. The soloist copes magnificently with the technical demands, full-on for 20 minutes at a time. It is good that works like this are still being discovered and recorded. The consummate mastery of the Symphony No. 4 (1960) shows Giannini at the height of his powers.

Gunther Schuller, now in his 80s, has slid into an elder statesman role with such ease that it is quite hard to imagine him in the late 1950s as a radical figure seeking to fuse classical and jazz idioms. The three works from this period stem from his drive to complete what he regarded as unfinished business from the 1920s when, briefly, Gershwin, Copland and others saw the potential for the two streams to be moulded. Certainly interesting, but the middle work, with narrator, is rather less so. Michael Daugherty's whimsical Sunset Strip evokes memories of 1950s Los Angeles and the beat generation. Daugherty has a strong affinity for retro-pop culture and has written a number of pieces on similar themes such as Hell's Angels and Route 66. His music is direct and appealingly extrovert. John Williams is more introspective and fantasy-oriented, perhaps a consequence of years of writing music for Steven Spielberg movies! Escapades, from another recent film score, has been fashioned into a mini alto saxophone concerto (in 2009 Williams has also had a new Harp Concerto and Viola Concerto premièred). Lions (1963) by Ned Rorem (receiving its first recording in 40 years) is one of his most exquisite orchestral fantasies, a dream-sequence of an encounter with a family of lions in a house as an imaginary jazz quartet plays. There is a Rabelaisian irreverence and jocosity about Christopher Rouse's music, and the French connexion is in evidence in Friandises (or 'morsels'), a neo-baroque suite with occasional rude and brash interruptions from a more contemporary age.

2009 is the bicentenary of Lincoln's birth and Naxos have put together a 2-CD set of the familiar (Copland's Lincoln Portrait) and the unfamiliar. Vincent Persichetti's A Lincoln Address evoked a storm at the time of Richard Nixon's second inauguration (the Inauguration Committee asked for the score to be excised of a number of Civil War references). The ensuing publicity ensured it did get played but it has languished for over three decades. Ernst Bacon (1898-1990) has languished too, which is a pity since he wrote many interesting and well-crafted works, including several symphonies and other pieces which must be worthy of exploration. Ford's Theatre (1946), a series of 
elegiac and thoughtful sketches, was recorded in the early days of LP and was quite widely heard in the USA 60 or so years ago, often with Bacon as conductor. It reflects the composer's dignified and unsentimental admiration and reverence for the 16th President. Morton Gould was a young man who in the patriotic fervour of 1940s America recognized an opportunity to celebrate in music a national icon. Lincoln Legend, although premièred by Toscanini, faded too, and probably has not been heard again until now. The Gould formula of vernacular and sacred song shaken up into a cocktail of jazz and razzmatazz is effected with the usual dash and energy. The Turok and McKay pieces are pleasant interludes but with less to offer than Ives and Harris. (Rumour had it last year that Naxos were going to release Jaromir Weinberger's Abraham Lincoln Symphony...)

These Naxos CD bargains are holding their own in the face of ever-increasing competition from downloads.

Bret Johnson

FRITZ BRUN: Symphony No. 5 in E flat; Symphony No. 10 in B flat. Moscow Symphony Orchestra c. Adriano. Guild GMCD 7320.

FRITZ BRUN: Symphony No. 8 in A major'; Variations on an Original Theme for string orchestra and piano $^{2}$. ${ }^{1}$ Studio-Orchester Beromünster c. composer, ${ }^{2}$ Collegium Musicum Zürich, Adrian Aeschbacher (pno), c. Paul Sacher. Guild GHCD 2351.

HANS SCHAEUBLE: Sonata No. 2 for violin and piano. HINDEMITH: Violin Sonata in E major. REGER: Violin Sonata in C minor, op. 139. FURTWÄNGLER: Sonata No. 1 for violin and piano. Bettina Boller (vln), Walter Prossnitz (pno). Guild GMCD 7326/ 7.

The year 2009 marks the 50th anniversary of Fritz Brun's death in his native Switzerland. It's good to have a recording of one of his ten symphonies conducted by the composer, as well as first recordings of two further works in Adriano's orchestral cycle for Guild. The Moscow Symphony Orchestra's performance of the Fifth Symphony under his baton is highly impressive. Distinct echoes of Beethoven and Brahms, often present in the earlier symphonies, are again in evidence: Brun himself mentioned a preparatory study of Beethoven to Hermann Scherchen. Apart from a double bassoon and bass tuba, the orchestra doesn't exceed classical dimensions. The first movement takes the form of a chaconne, one of whose variations provides the subject of a skittish second-move- ment nocturne. This is succeeded by a funeral march, an eloquent lament for Brun's deceased colleague Hermann Suter. In his final movement, the composer vents his spleen over Suter's fate. Headed Rasch und wütend ('fast and furious'), the finale begins fugally and weaves further variations on the work's initial theme.

A long time ago Brun's opening chaconne - it could easily be taken for a closing movement - appeared on a recording under Schoenberg's Swiss pupil Erich Schmid. Brun regarded his Fifth as a personal response to the break-up of classical tonality, one that was orientated towards Stravinsky rather than Schoenberg. Deep down, however, the neo-Romantic language is unmistakably his own, and the chaconne seems more original every time I hear it. The solo oboe, horn, violin and cello execute their solo variations with finesse.

Fritz Brun's sunnier side emerges from the Tenth Symphony, which was completed by the shores of Lake Lugano in 1953 (the date is inadvertently transposed on the back of the CD case). Like the Second Symphony of 1909, but in a more compressed form, it recalls the exuberance of Schumann's 'Spring' Symphony in the same key. Rhapsodic in spirit, the third-movement Adagio shows Brun's variation technique at its most imaginative. Again the performance as a whole underlines his creative stature, long obscured by his native reputation as a conductor in Berne.

He appears as conductor of his own music on a remastering of a rather cavernous 1946 radio recording preserved in the Zurich Central Library. The Eighth Symphony is one of Brun's most expansive works, recalling his abiding fondness for Bruckner in that respect. While carrying a programme describing the times of day, the symphony adheres to a traditional movement-order, starting with the activity of high noon and ending with a new day. The enchanted second movement derives from a Bernese folk song addressed to Hesperus, the evening star. Then Brun conjures a nocturnal landscape, less agitated than his Fifth Symphony's Berliozian visions. Throughout the work, the rhythmic and harmonic invention is considerable.

The Eighth Symphony has been coupled by Guild with Paul Sacher's 1946 recording of another fine late work, Variations on an Original Theme. Whereas the Tenth Symphony features concerto grosso-like writing for wind instruments, here a similar technique is applied to the strings. Lyrical nostalgia is the dominant impression, but the solo piano (Brun's own instrument) maintains a vital pulse.

Like Mahler and other full-time conductors, 
Fritz Brun had to be a Sommerkomponist for much of his life. His output did, however, grow steadily, unlike that of his contemporary Wilhelm Furtwängler. The latter's First Violin Sonata, WF 113 , occupied Furtwängler on and off for roughly 20 years, eventually receiving its première in 1937. There is a recording from the 1990 s made by Dong-Suk Kang with François Kerdoncuff. More recently the Swiss-born violinist Bettina Boller has been playing the piece in recitals. The verve she brought to recordings of concertos by Othmar Schoeck, Hermann Suter and Wladimir Vogel made her new double $\mathrm{CD}$ an appealing prospect.

Nor does Boller disappoint with her Furtwängler recording. When the great man writes Immer steigern, aber dasselbe Tempo bleiben ('Keep intensifying, but in the same tempo'), the violinist and herkeyboard partnerWalter Prossnitz know exactly what he meant. Furtwängler's writing has two things in common with Fritz Brun's: a near-Brucknerian constructional span and a virtually self-contained first movement. Deftly observant of dynamic and harmonic shifts, the duo expound the Sonata's emotional argument with conviction.

When he learnt that Hindemith's compositions had been vetoed by the Third Reich, Furtwängler objected that the officially acceptable Reger was less harmless than he seemed. Boller brings the required passion and subtlety to Reger's capacious Sonata in C minor, op. 139, and she makes each note count in Hindemith's two-movement Sonata in E of 1935. The Swiss composer Hans Schaeuble is not out of place in such company. His Second Violin Sonata (1946) reflects that stylistic eclecticism discussed by Annalise Plummer in Tempo No. 218 - and also his mastery of extended finales. With Prossnitz, Bettina Boller reveals the inherent warmth of this music.

Peter Palmer

LEES: Toccata; Six Ornamental Etudes; Three Preludes; Sonata Breve; Odyssey. Mirian Conti (pf). Toccata Classics TOCC 0069.

Benjamin Lees celebrated his 85 th birthday in January 2009 and remains as active as ever. His Third Piano Concerto was premièred in Florida in 2007 and recently he has completed his Third Piano Trio (due for première at Dartington this summer), an organ work (his first for the instrument) and a new piano piece for Barbara Nissman. As of April 2009 he is about to start a new orchestral work. This new CD of his piano music covers almost the entire span of his career so far from 1947 to 2005 . There can be few examples in the whole of music literature of sustained assuredness and consistency of stylistic quality. The very early Toccata, written when he was only 23 , possesses a rugged muscularity also found in the music of Lees's mentor George Antheil, even though they had not yet met.

In fact Lees has been strongly influenced by Antheil's ethos of propulsive meters and edgy ostinati: indeed he describes himself as a 'visceral' composer. Yet the strength of character of all of Lees's music is moulded and informed by several aesthetic influences. In 1954 he settled in France for several years and became fascinated with surrealist art; its vivid and sometimes perverse imagery became a strong influence in his keyboard music. It can be strongly detected in the brief but greatly contrasting Six Ornamental Etudes of 1957, in which imagery alternates between the graphic and the reflective, but the landscapes are abstracts of mood and demeanour rather than visual portraits. The Sonata Breve from the same period also exhibits a range of contrasts, but this time within a tight one-movement sonata structure, cast almost as a tone poem. The music carries a powerful narrative force, as does all Lees's music: it knows exactly where it is going and the listener is swept along by an exalted rhetoric of utterance. Lees represents an artistic ethic that draws deeply on the noblest aspirations of the human spirit: his lifelong quest for inner truth and integrity has never wavered and his canon of work will always remain a shining monument to humanity's dogged determination to affirm life and all the best that it brings.

The Three Preludes of 1962, written for the pianist Joseph Bloch, display Ravelian brilliance, recalling that of Gaspard de la Nuit. Lees describes how the three works entitled Odyssey came to be written over a period of 35 years. No. 1 was composed for John Ogdon, and is an exploration of textures and techniques. Again the mention of 'surrealist landscape' reminds us of Lees's aesthetic, and evokes the notion of a journey. The second (1986) is a successor but a more complex one, and the third (2005), written for the present artist Mirian Conti, is, according to the composer, even more 'disturbing' than the other two. Mirian Conti adds her own illuminating comments to those of the composer and expresses her high regard for the three Odyssey works. It is especially gratifying when a composer finds a champion performer and the artistic synthesis which ensues. This latest release of Lees's music will do him nothing but good: the quality of his workmanship and the compelling authority of his technique pro- 
vide further evidence of a lifetime spent enriching the literature of serious American music. This disc is strongly recommended, the quality of playing, recording and production is unlikely to be surpassed.

Bret Johnson

MORTON FELDMAN: Patterns in a chromatic field ${ }^{1}$; Projection I; Composition - Eight Little Pieces ${ }^{1}$; Intersection IV; Duration $I I^{1}$. Arne Deforce (vlc) with ${ }^{1}$ Yutaka Oya (pno). Aeon AECD 0977 (2CD-set).

Arne Deforce's booklet notes for this release comprise a collection of text fragments from Feldman's Give My Regards to Eighth Street and Morton Feldman says. The snippets give windows into Feldman's creative processes, perhaps the most telling of which is "my desire was not to "compose", but to project sounds into time, free from a compositional rhetoric that had no place here'. The quotations are also intensely relevant to the works presented and shed much light on Feldman's aesthetic.

Feldman's expansive pieces invoke a kind of meditative stasis in their use of ostinati and their predilection towards silence. Recently, I reviewed For Christian Wolff (Bridge 9279) for these pages, a piece that lasts just under three hours. Written five years earlier, Patterns in a chromatic field for cello and piano exhibits the characteristics of late Feldman perfectly. There are explosions of sound, unpredictable in their placings. Functionality is effectively neutralized, in that gestures which may present themselves as important simply may never be heard again. The musical surface invites speculation on the part of the listener - despite the mesmeric qualities of the general quiet and stasis, part of the listening experience is undeniably active in nature.

Feldman was concerned with freedom, in emancipating the various parameters, but at the same time he was obsessed with permutation. 'Do it one way and do it another. Spell it one way, then spell it another way', as he himself put it. At the heart of the process of emancipation is that of freeing time ('I am interested in how the wild beast lives in the jungle - not in the zoo', said Feldman). His most telling comment is possibly, 'For me sound was the hero, and still is. I feel that I am subservient'. The sounds give him life. There are so many contradictions here. The music can be heart-stoppingly delicate, and yet still project its own eternal indestructability. The use of more emotional sections, such as the pleading upward cello glissandi of the second track of disc 2 , are all the more pronounced for their rarity. Arne Deforce's control of his instrument is masterly (listen to the extended repetitions of whispered harmonics, each perfectly rendered, on Disc 1); Yukata Oya is almost as sensitive.

The remaining four pieces are dwarfed by Patterns in a chromatic field. Projection I (1950) for solo cello lasts a mere 2'52" but was seminal in its grid-like notation; Composition, 4'18"; Intersection IV, 3'08'; Duration II, 6'03'. Feldman's five pieces called Projections are graphic works, while Duration II specifies pitch but not other parameters - the instrumentalists begin together but continue in their own ways. Composition - eight little pieces (1950) is Webernian in utterance, but the material is perhaps even more aphoristic, and certainly more insubstantial. The predominantly quiet dynamic emphasizes the fragility of the exercise, while Intersection IV concentrates on the creation of wide registral spaces. Duration II seems, in this performance, to be a study in stillness.

Required listening for any Feldman admirer, and a valuable addition to the catalogue.

Colin Clarke

HOIBY: The Tempest. Purchase Opera, Purchase Symphony Orchestra c. Hugh Murphy. Albany TROY 1106/1107 (2-CD set).

HOIBY: 21 songs and a Duet. Julia Faulkner (sop), Andrew Garland (bar), Lee Hoiby (pno). Naxos American Classics 8.559375.

PaUluS: To Be Certain of the Dawn. Barry Abelson (cantor), Elizabeth Futral (sop), Christina Baldwin (mezzo-sop), John Tessier (ten), Philip Cokorinos (bassbar), Minnesota Chorale, Minnesota Boychoir, Basilica Cathedral Choir, Minnesota Orchestra c. Osmo Vänskä. BIS-CD-1726,

Lee Hoiby (b. 1926) and Carlisle Floyd (also b. 1926) are perhaps the two pre-eminent living American opera composers in the tradition of Barber and Menotti. Floyd has devoted virtually his entire life to the medium, whereas Hoiby has written many concert and orchestral works, ballets, two piano concertos, songs, chamber music and a sizeable body of music for the church. His early opera Beatrice, from the 1950s, appeared on the Louisville Orchestra label and since the 1970s a steady flow of operas has emerged: Summer and Smoke (1971), The Tempest (1986), This Is The Rill Speaking (1992) and most recently Romeo and Juliet (2004), which still awaits performance. 
The Tempest is a substantial and forceful musical drama in three acts. The action of Shakespeare has been converted into a libretto by Mark Shulgasser, and was substantially revised in 1996, with nearly half an hour cut from the original three-hour score. Turning Shakespeare inside out, re-ordering and abridging the text can be a high-risk strategy, especially where the plot is diffuse and, as with The Tempest, somewhat contrived to say the least. It can also dangerously alter the characterization of the main roles. It seems to work here, however, although there are some instances where already obscure verse is rendered even more obscure by altering its context - for example in one of Prospero's early speeches in Act 1 (CD1 Track 2) where I momentarily lost the sense altogether. One cannot but accept however that the text had to be modified for operatic purposes, so as to prevent the opera sprawling out to four hours.

Moreover, some roles are very demanding indeed, especially that of Ariel, often pitted for long periods against a surging orchestral palette. The music is exceptionally lyrical and tuneful and at times very exotic - especially where Ariel and the sprites are concerned: tuned percussion, harp, celeste, piano and glockenspiel and long lyrical vocalises conjure up thoughts of Szymanowski (King Roger) or even Bernard Herrmann (Wuthering Heights). The drama certainly works on CD and the music pulls you in to this very attractive work, which appears to have been the subject of a lavish production by the Purchase Opera of New York. The love duet between Ferdinand and Miranda in Act 3 contains some of the loveliest music. Hoiby has that rare ability to sustain a line both vocally and orchestrally over long periods.

This is present-day grand opera using the full resources of musical theatre. The moderately large orchestra takes a leading role and at times achieves almost Straussian power. Maybe sharper musical definition of some characters would have made for an even more effective drama, for instance those of Prospero and Alonso, and Stefano and Antonio (although those two are a bit shadowy in the play). Ariel is invariably magnificent, and the ending is a brilliantly effective drawing together all the characters in a massive musical pageant. This is an enjoyable studio recording which comes off well with good soloists and very presentable orchestra. The music is glorious and ranks with the best I have ever heard by Hoiby, who on the strength of this achievement deserves to be much better known.

Hoiby's songs are, according to the sleeve notes, the medium for which he is best known. Whilst studying in Rome in the early 1950s, he was criticized for writing in a dated style. 'I wanted to grow heirloom roses but they allowed you only cactuses!' The influence of Barber, but also of Schubert (a lifelong hero) is striking. The songs span over 50 years, Hoiby's entire life as a composer. The texts are mainly taken from 19th- and 20th-century English and American poetry (Blake, Hardy, Whitman, Emma Lazarus). Not previously knowing many Hoiby songs I was unprepared for the treasure which awaited me. His setting of Blake's 'The Lamb' is timeless. So too is 'Lied de Liebe' and 'Nuits'. He proves an excellent accompanist, too, on this disc, including one number ('Evening', by Wallace Stevens) which Leontyne Price regularly sang with him. His songs are models of taste and character.

If you need any evidence of Lee Hoiby's status as a Renaissance man, go no further than these two releases, and start with the songs.

Stephen Paulus celebrated his 60th birthday in August 2009. He is in huge demand as a composer, receiving many commissions from a wide range of organizations in the USA and elsewhere, especially churches and choirs, vocalists, orchestras and music schools. He remains under-represented on CD, however. With well over 350 works to his credit, the last few years alone have seen the completion of a very lyrical and vibrant Concerto for Two Trumpets and Orchestra (2003), a fine orchestral song cycle for Deborah Voigt, Erotic Spirits (2005), a Concerto for Piano and Winds (2006) and a large cantata A Procession of Seasons (2007). August 2009 saw the unveiling of a new Cello Concerto for Lynn Harrell and the Grand Teton Music Festival, and an orchestral cycle of poems by Dylan Thomas will be premièred in Tucson in late October 2009.

However Paulus's most important recent work is To Be Certain of the Dawn (2005), an hour-long cantata commissioned as a gift to a synagogue in Minneapolis to commemorate the 60th anniversary of the liberation of the Nazi death camps in 1945. Since its première in Minneapolis four years ago the work has been widely performed in America and Europe and its very approachable idiom, sympathetic texts (by Michael Dennis Browne) and the inclusion of a major choral role for children have generated strong popular appeal. The work is focused on the million-and-a-half children who perished, and Browne says the children represent 'the sun, moon and stars'. The work's ethos takes it beyond the terror and cruelty of the Holocaust by appealing to the spirit of humanity, of reconciliation, love and healing. Indeed, the final words sung (in Hebrew) are: 'Love your neighbour as yourself'. The opening section, 'Renewal', contains some of the most animated music (a shofar, or ram's horn, is heard at various 
points), prefaced by the Cantor's intonation: 'Hear, O Israel'. But far from being an overtly dramatic work (in the manner of, for example, Benjamin Lees's Symphony No. 4 Memorial Candles, a major Holocaust symphony from the 1980s), the power of this music derives from its inner struggle to find peace and, if not closure, then at least a modus vivendi. The passage of time may not heal completely but it can bring pause for quieter reflection and there are many passages of tenderness and poignancy. I was particularly moved by the opening of the second of the work's three parts: 'We are just two little girls in the street, sisters? What do you think? Do you like the pretty red coat ...?'

The composer achieves a balance of narrative by alternating children's choir (sometimes in Hebrew) with the main chorus and soloists. The texts, by focusing on individuals or small groups rather than on huge numbers, remind us of the incomprehensible enormity of the sum total of each personal story. The middle section, 'Remembrance', has the children's choir singing a number of Hebrew blessings, and a Hymn to the Eternal Flame: 'Every face is in you, every voice, every sorrow, every pity ...'. The piece ends with a final section, 'Visions', in which memories combine with hope for the future. There is, too, the guilt of the survivor: 'Why did I survive?' 'God kept you on earth to write the story'.

This is an important landmark in the long procession of artistic responses to what was probably the greatest crime in human history. Paulus (and his librettist) have created a sensitive and pantheistic memorial.

Bret Johnson

JUDITH BAILEY: String Quartet, op. 31; Clarinet Quintet, op. 47; The Towers of San Gimignano, op. 51; The Egloshayle Nightingale Trio, op. 59; Aquamarine Waltz, op. 65; Microminiature No. 1, op. 68; Microminiature No. 2, op. 70; Visions of Hildegard, op. 72; Light, op. 76. Davey Chamber Ensemble. Metier MSVCD92101.

NATASHA BARRETT: Trade Winds. Aurora ACD5056 (SACD).

EVE BEGLARIAN: The Marriage of Heaven and Hell ${ }^{1,7}$; Creating the World ${ }^{2,8}$; Robin Redbreast ${ }^{3,5}$; Wonder Counselor for organ and tape; Landscaping for Privacy ${ }^{4}$; FlamingO ${ }^{6,9}$. ${ }^{1}$ Lisal Bielawa (voice), ${ }^{2}$ Roger Rees (voice), Jessica Gould (sop), ${ }^{3}$ Corey Dargel (voice), ${ }^{4}$ Eve Beglarian (voice, perc), ${ }^{5}$ Margaret Lancaster (picc), ${ }^{6}$ Bill Ware (vibes), ${ }^{7}$ MATA Ensemble, ${ }^{8}$ Paul Dresher Ensemble Electroacoustic Band, ${ }^{9}$ Ensemble c. Brad Lubman. New World 80630-2.
BARBARA BENARY: Aural Shoehorning ${ }^{4}$; Sun on Snow ${ }^{1}$; Barang $I^{2}$; Barang $\mathrm{II}^{2-3}$; Downtown Steel. ${ }^{1}$ Phyllis Clark (sop), ${ }^{2}$ Steven Silversten (cl), ${ }^{3}$ Peter Thompson (cl), ${ }^{4}$ Gamelan Son of Lion, DownTown Ensemble. New World 80646-2.

BRITTA BYSTRÖM: Persuasion; The Baron in the Trees ${ }^{1}$; Farewell Variations; A Study in Scarlet; Sera; Aria from the opera If You Lose Your Luggage ${ }^{2}{ }^{1}$ Mika Takehara (perc), ${ }^{2}$ Agneta Eichenholz (sop), Västerås Sinfonietta c. Hannu Koivula. Phono Suecia PSCD 174.

SILVINA MILSTEIN: of lavender light ... ${ }^{1}$, the unending rose I \& II ${ }^{2}$; fire dressed in black; cristales y susurros; tigres azules. ${ }^{1}$ Alison Wells (mezzo-sop), ${ }^{2}$ Caroline Balding (vln), Lontano c. Odaline de la Martinez. Lorelt LNT129.

Although the C.V. of Barbara Benary (b. 1946) is long and distinguished - charting a varied career as performer (on violin, Hardanger fiddle and gamelan not least; she was an early collaborator of Philip Glass) and novelist - as a composer she is largely a local phenomenon within the thriving New York new music scene. During her studies in the 1960s she instinctively reacted away from dodecaphony and serialism (although John Cage was, and remains, a seminal influence), following rather the path of an ethnomusicologist, from which her own compositional voice began to emerge in the 1970s. Her output is modest in size, including unaccompanied instrumental works, chamber music, pieces for gamelan-style ensembles and theatre pieces such as her shadow-puppet opera Karna (1994). The range of her expressive mélange is illustrated on the one hand by Wayang Esther (2001, subtitled 'A Javanese Purimspiel'), an operatic retelling of the Biblical story of Esther for Indonesian shadows puppets with gamelan accompaniment, and, on the other, Tamil Quartets (2007) mixing string quartet with tabla and other Indian drums.

The two Barang pieces included on New World's release are amongst her earliest extant pieces, part of a set of four from 1975 in which one or two melody instruments weave euphonious lines strongly influenced by Indonesian music. (Benary studied Indian and Indonesian music but it is Javanese music that had the most longlasting impact on her own works.) She seems to have had the flute in mind when writing Barang I, but both pieces work very nicely on the clarinet. Indeed, listening to the two of them together they form a beguiling diptych, the single line of the first amplified by the interwoven textures of the second. Interweaving lines are a fundamental aspect of Benary's work, as her series of Braid pieces from the late 1970s and 1980s demonstrate. These generally follow a gently euphonious 
course, not unlike traditional Javanese music (and unlike the harder tones of the modern Balinese 'gong kebyar' style).

A more volatile element entered Benary's music in the 1990s, as exemplified by two other works here. Downtown Steel (1993) is a vibrant octet for clarinet, saxophone, trombone, tuba and four percussionists which uses gamelanstyle sonorities and textures in a purely Western context. The two untitled movements alternate music of toccata-like vigour with moments of reflection - for example in the quiet coda - that succeeds in reconciling if not fusing its disparate raw elements. In the largest (and most recent) work presented, Aural Shoehorning (1997 - the title derives from a critic's comment: now there's a first), Benary juxtaposes western and Indonesian instruments, with their different tunings, within a single design, with marvellous results, especially at those points of genuine crossover, as in the coda to the opening 'Plainsong', where the main theme moves from gamelan to piano. The effect is like looking at an object in the flesh and then at its reflection in a lake: the object is fundamentally the same, but the reflection both loses something from the original and supplies a fresh perspective. As the work proceeds, the two ensembles overlap, intermingle and fuse with by turns menacing, eerie and exhilarating effect.

The title work of New World's disc is Sun on Snow (1985), a vocal-plus-instrumental septet (which can be performed by one or two sopranos with 5-8 accompanists) in five movements that play continuously. The piece sets an anagrammatic nature poem consisting of 25 words arranged in five lines of five words apiece. Quieter, more spiritual than the two other ensemble pieces, it lies stylistically mid-way between the contemplative Barangs and the vivacious Downtown Steel. The use of an electric guitar strikes a curiously surreal note, sounding fleetingly like an escapee from Mike Oldfield's Tubular Bells, but it exemplifies another occasional trend in Benary's eclectic make-up: a kind of underground assimilation of jazz. Big band textures in particular make cameo appearances in both Aural Shoehorning and Downtown Steel. The works are performed by members of New York's DownTown Ensemble and the Gamelan Son of Lion, which was cofounded by Benary in 1976 (the Gamelan's name is a translation of her Hebrew surname; it is notable how little overt Jewishness is evident in the works presented here). Benary herself appears in the gamelan in Aural Shoehorning, as the violinist in Sun on Snow and as a percussionist in Downtown Steel. New World's sound is first-rate as is the disc all in all.
Eve Beglarian (b. 1958) is the daughter of the distinguished American academic and composer Grant Beglarian. Where Benary's music is predominantly gentle, veering towards vigorous, Beglarian's is brash, volatile and exuberantly in-your-face. It has its moments of quietude and repose, as at the outset of Creating the World (1996), a surreal, quarter-hour multi-genre setting for speaker, soprano and sextet (including electric guitar and mallet percussion) of Czesław Miłosz's irreverent poem. Beglarian's freewheeling setting of the poem (here featuring British actor Roger Rees in splendid voice) creates an atmosphere close to the spirit of The Hitch-hiker's Guide to the Galaxy and ends with a rollicking dance owing much to modern jazz and rock, although the work's ethos is fundamentally Classical. The Marriage of Heaven and Hell (1994) is of similar dimensions and (as the title suggests) built around words by William Blake. Here, though, the text is less central to the whole, assembled from fragments stitched into the instrumental fabric and declaimed or sung (here by soprano-composer Lisa Bielawa). The influence of minimalism is felt most heavily in this piece, the wind-based sound-world not unlike Michael Nyman but with a distinctly New York accent.

By contrast, the brief Robin Redbreast (2003) is a quiet, sombre song for voice, piccolo and electronics to a sad poem by Stanley Kunitz concerning the death of a robin. Like the instrumental Wonder Counselor (1996) for organ and tape (the organist is not credited) Robin Redbreast is basically a single-mood piece which weaves along its doleful path in under five minutes. Wonder Counselor is more developmental, though Beglarian's sense of humour is apparent in the accompaniment which includes the sound of an erotic encounter. In Landscaping for Privacy (1995), the composer is heard declaiming Linda Norton's poem (not reproduced in the booklet), emphasizing the text's nice irony, over an undulating piano accompaniment originally designed to be performed on tape but later recast for a live performer. Since the pianist is not credited here, I assume the tape original is reproduced.

New World's finale is another instrumental, FlamingO (1995, rev. 2004), for a small orchestra of wind quintet plus cor anglais, trumpet, trombone, piano, percussion, string trio and double bass, but with a prominent solo for vibraphone and taped samples (including the cries of the eponymous wading bird). This is another raucous invention full of teeming lines, vivid textures and a melange of different styles and moods. It is given a thunderously committed performance by its 15 executants and brings the disc to a rousing 
conclusion, though the work ends with a fade-out. New World's sound is once again very fine.

Silvina Milstein (b. 1956) is Argentinian by birth but has been a UK resident since the military coup in her homeland in 1976. A former pupil of Weir and Cresswell in Glasgow and Goehr in Cambridge, she is currently Senior Lecturer at King's College, London. Unlike both Benary and Beglarian, who reacted away from the atonality and serialism of their student days and academe into more audience-friendly styles, Milstein has remained within the modernist camp. The six works on Lontano's new disc provide a good overview of her music between 1997 (of lavender light ...) and 2005 (cristales y susurrus), exhibiting her flair for lyrical writing, her command of instrumental line and ability to create often succinct, satisfying musical structures. The single unbroken lines of the solo violin works, the unending rose (1999), show these traits at their most pared down, shorn of all inessentials, yet still poetic in expression if a touch austere in texture. The title derives from a poem by Jorge Luis Borges about a Sufi poet's musings to the rose of the title, its spirit reflected in the epigraph of the First, 'And told her in words that had no sound'. No. 2 took its inspiration from the final act of Shakespeare's Anthony and Cleopatra, specifically from Cleopatra's death and her dying gesture of defiance ' I am fire and air ...' and is perhaps more theatrical in expressive profile.

Curiously, the one Milstein work here to feature the human voice, in a setting of a richly erotic poem by San Juan de la Cruz which one can imagine Eve Beglarian relishing to the full, I found the most opaque expressively. Fire dressed in black (2002) was originally written for mezzo-soprano, cello and piano but is given here in its expanded revision with clarinet. Despite the extra richness of texture provided by the wind player, fire dressed in black remains stubbornly aloof emotionally, its music not touching the subtleties of the verse, which describes a lover's clandestine creeping through a darkened house at night to meet his beloved. The problem, I suspect, is the musical language: Milstein's atonal harmonies cannot express the thrilling sensations of expectancy and lust of de la Cruz's ardent lover, nor the essential lightness of the text.

Milstein is stronger with more abstract designs and less direct inspiration, as with cristales $y$ susurrus ('Whispering crystals', 2005), given here in its original version for a septet of flute doubling piccolo, clarinet doubling bass clarinet, harp, string trio and double bass (an alternative version for piano quintet exists). Here a tapestry of 'evocative gestures drawn for the vernacular of Buenos
Aires proliferate echoing the ripples left by the pleasures and intimacy of a magical night'. The physicality and ardour so lacking in fire dressed in black is here in full measure, and a musical portrait emerges of the Argentine capital rather different to the one provided by Piazzola. The flow of ideas and their developments is in marked contrast to of lavender light, for 11 players, in which Milstein composed 'lightly tinted silences' mimicking the bald spots in some Cezanne artworks (although the title refers to Van Gogh). Milstein controls the contrasts in tone and texture admirably but on the whole of lavender light is less effective than cristales $y$ susurrus and both fall sort of tigres azules ('Blue tigers", 2003), which is by some way the most vivid and vibrant work on offer. It is written for a small orchestra of 15, for the London Sinfonietta, divided into two groups in the manner of a concerto grosso: a continuo of harpsichord, piano, harp, celesta and percussion and a concerto of wind and string quintets. The blue tigers of the title again derive from Borges and India but one needs no special knowledge to appreciate its ineluctable rhythmic and expressive flow. Lontano's performances are superb (as always) as is the sound and John Taylor's production.

Judith Bailey (1941) is a local composerly phenomenon similar to Benary and Beglarian, though rooted in her native Cornwall (for which she was invested as a Bard of the Gorseth in 2005), rather than New York. Metier's disc features eight instrumental works, written between 1987 and 2004, presented chronologically and framed by music inspired by the deaths of the composer's mother (the String Quartet) and her long-time partner (Light). All the works tend to the brief, only one-Light-reaching to the teens of minutes; and of their 26 movements only two, the opening spans of the Quartet and the piano suite The Towers of San Gimignano (1993), extend past five minutes in duration. (Half of them last less than two.) A variety of standard genres are represented, from clarinet quintet, quartets (strings and clarinetviolin-cello-piano: Visions of Hildegard, 2001), string trio (The Egloshayle Nightingale Trio and Microminiature No. 2), piano trio (Microminiature No. 1, although Light is a variant, swapping cello for viola), cello-and-piano (Aquamarine Waltz, 1999) and solo piano.

For the most part, Bailey's music is quiet and reflective, tonally based (often diatonic), the textures often spare and atmospheric. Extramusical resonances abound, though none are declared for the Clarinet Quintet (1993), featuring the composer's own instrument. Its brevity (lasting here a little past eight minutes) may seem unduly lightweight when compared to the 
standard repertoire (think Brahms, Reger, even Hindemith) or indicative of a short-windedness in Bailey's ideas. Rather, I see this work as being a sonatina next to such pieces, the three miniature movements exploring the basic texture of the medium and enjoying themselves while they do so. Of more weight is The Towers of San Gimignano, inspired by the famous Tuscan town, its first two movements the finest music on the disc. The finale, however, while pleasing enough, does not quite match what has gone before, as if ghosting in from another piece.

All the works here sound grateful to play, allowing the performers plenty of scope for expression and direct communication with their audiences, unclouded by the complexities of compositional isms. Not that Bailey's music is undemanding per se, as the graver sections of Light show, with their subtle shadings and alternations of light and dark weaving a moving tapestry of grief, loss and consolation. In the two Microminiatures (2000) - deliberately written to play for 3-4 minutes - the remit for the commission was for tiny works for amateur performers; note the late-Shostakovich-like momentum of No 2's final Allegro. If slight in size they are not unengaging to hear. While heavenly length is no guarantee of musical profundity, it is true that only the three-movement Quartet and four-span Light really punch above their weight. The performances, by the members of the Davey Chamber Ensemble, for whom several of the works were written, are generally acceptable although there are some problems of intonation in the larger-ensemble works, particularly in the Adagio of the String Quartet and the opening of Visions of Hildegard, the latter a nicely-worked, undemanding variation-fantasy on a theme by the medieval Abbess of Bingen. Metier's recording, made in Bath Spa University in 207, is clear if very close-miked (almost claustrophobic), not allowing much room for the music to breathe.

For those unfamiliar with the term 'acousmatic music' (broadly, music which one cannot see being played: so theoretically including any recorded medium), Natasha Barrett's Trade Winds (2004-6) is a good example, a 52-minute composition inspired by the ocean and specifically its 'vast expanse'. Its eight movements - Opening, Submerged, Open Ocean, Mobilis in Mobili (inspired by Jules Verne's 20,000 Leagues Under The Sea: this movement can be played separately), Deep Layer, Planctonic Float, Migration and Nordfjorden Shore - are constructed from a variety of pre-recorded elements, concrete sounds of the sea and sea birds, organ chords, the soprano Jane Manning, a roofraising but all-too-brief sea shanty (performed with gusto by the Storm Weather Shanty Choir) and reminiscences from the retired Norwegian trawler captain, Jon Warhuus (spelled Varhus on the composer's website), concerning a perilous journey to the Aleutian Islands during a Pacific storm.

The Nordic resonances are to be expected, as Barrett has been resident in Britain's northeasterly neighbour for a decade, and the landscape and culture of Norway are closely bound up with her work - a fact recognized in the award of the Nordic Council's Music Prize to her in 2006. Trade Winds was commissioned by NoTAM with funds provided by the Norwegian Composers' Fund and Norwegian Cultural Council and in structure resembles a large-scale tone poem or suite, highly descriptive of the sea and at times elemental in its power. The use of spoken Norwegian is not an issue for non-Norwegian speakers as it is as much the texture and sonority of the voice that is important as the spoken words themselves; Aurora provide a full translation in English in the booklet nonetheless.

The recording presents in SACD format a stereophonic representation of Barrett's original 16-channel concert version (which has a video element created by Marianne Selsjord), which used antiphonally placed speakers to maximize spatial separation. Although there is some loss of effect on disc compared to the concert version, Aurora's recording presents an otherwise faithful representation of Barrett's central vision.

Persuasion is the title track of a new Phono Suecia release devoted to orchestral music by the Swedish composer Britta Byström (b. 1977). Commissioned for a conducting composition, the allusion toJane Austen's novel is deliberate (indeed, literature is a key starting-point for several of the works in the programme) and translates into a metaphor for the novel where the conductor-cumsuitor attempts to 'convince the orchestra about his intentions'. It is a curious conceit but, alas, not entirely persuasive. To most, Persuasion (2004) will sound like a moderately-paced, abstract orchestral toccata with a nicely balanced middle section, not illustrative of its external source. By contrast, the percussion concerto The Baron in the Trees (20001) - derived from Italo Calvino's comic novel - is more readily understandable as translating the essence of the book in the relationship between the soloist and orchestra, in a way similar to a pictorial representation, although the latter is necessarily of a single point in time. Eschewing wooden percussion for the most part, the soloist's metallic sounds give the music a brittle, fragile feeling that proves adaptable to both swift-paced and leisurely music. 
Haydn is the point of origin for the delightful Farewell Variations (2005), although only by example, as the theme which is the basis of the 14 highly contrasted and often amusing variations is of Byström's own invention. The theme and its treatments are not Haydnesque, either, even though the titles of the variations recall the titles (however apocryphally assigned) of many of the symphonies. It is a delightful piece and would make a splendid concert opener. So would A Study in Scarlet (1996). Tony Lundman's notes are a touch apologetic about this vigorous if somewhat stylistically anonymous diptych for string orchestra. What Lundman hears as impatience, rawness and agitation in this apprentice piece (her graduation was still some years away), I view rather as verve, inexperience perhaps in filtering influences, and sheer delight in the medium. By contrast, Sera (2002), Byström's graduation piece, shows a considerable increase in refinement and orchestral sensitivity. This journey through different musical landscapes, always in the evening light' is, for want of a better term, a tone poem in a long line of orchestral expositions of evening. As befits the subject, the toccata-like momentum of Persuasion and A Study in Scarlet is absent, the flow more reminiscent of an inter-related series of photographs or paintings. There's quick music aplenty, but beneath the surface activity the harmonic pulse is mostly rather slow if not static. Hannu Koivula directs sterling performances throughout from the Västerås Sinfonietta, providing excellent support to percussionist Mika Takehara and, in the radiant final aria from Byström's opera If You Lose Your Luggage (2003), soprano Agneta Eichenholz. The aria, which concludes the programme, reveals a lyricism not overly represented elsewhere in the couplings. Phono Suecia's sound is first-rate.

Guy Rickards
RODION SHCHEDRIN: The Sealed Angel. Marie Macklin (sop), Fiona Mackay (alto), Benedict Hymas (ten), Emma Walshe (sop), Nina Kanter (alto), Choir of Gonville \& Caius College, Cambridge, Choir of King's College, London, c. Geoffrey Webber, David Trendell. Delphian DCD34067.

As a child Rodion Shchedrin attended a choir school in Moscow, set up in 1944 on the direct instructions of Stalin. Shchedrin describes growing up singing sacred music by Bach, Haydn and Schubert given new, state-approved texts 'about the wonderful weather, the birds singing, the grass growing, praising the Motherland - just terrible'. Shchedrin had long intended to make his contribution to the Russian choral literature but, when the music was finished in 1988, he knew that to use his preferred title, Russian Liturgy, would mean that 'it would not have left my desk, despite perestroika'. So this contemplative setting of Old Slavonic prayers instead became The Sealed Angel, with passages from the Leskov novel of that name read between the nine musical movements. The piece duly received the Russian State Prize from Boris Yeltsin in 1992, and has been widely performed around the world.

The music has the smooth melodic contours and consonant modality of Russian church music. Firmly in the tradition of the settings of the Liturgy of St John Chrysostom by Rachmaninov and Tchaikovsky, The Sealed Angel has a similar ambience to that of the sacred works of Shchedrin's near contemporaries Pärt and Górecki. Largely slow and subdued, The Sealed Angel eschews the playfulness or eccentricity of much of Shchedrin's output for sincere expressiveness. There are only occasional outbursts, such as in the dramatic fourth movement, with its glissandos and foot-stamping. More typical is the gentle chorale that bookends the piece, wordless, wistful and affecting.

The singing of the combined choirs of Gonville \& Caius, Cambridge and King's College, London is warm and well blended, but perhaps too polite to put enough bite into the Russian consonants. The only instrumental accompaniment is an obbligato oboe, representing a flute-like Russian folk instrument and, by extension, the whole Russian people. Dancing lithely around the slowly treading music, Clare Wills's playing is one of the highlights of the recording, especially in the elusive solo movement at the centre of the piece.

Bernard Hughes 
CAMBRJDGE

\section{JOURNALS}

Knowledge is no longer shelved

The Cambridge Journals Digital Archive

contains more than 160 journals, more than

3 million pages and more than 8 million

linked references. Knowledge is now more

visible and more searchable than ever.
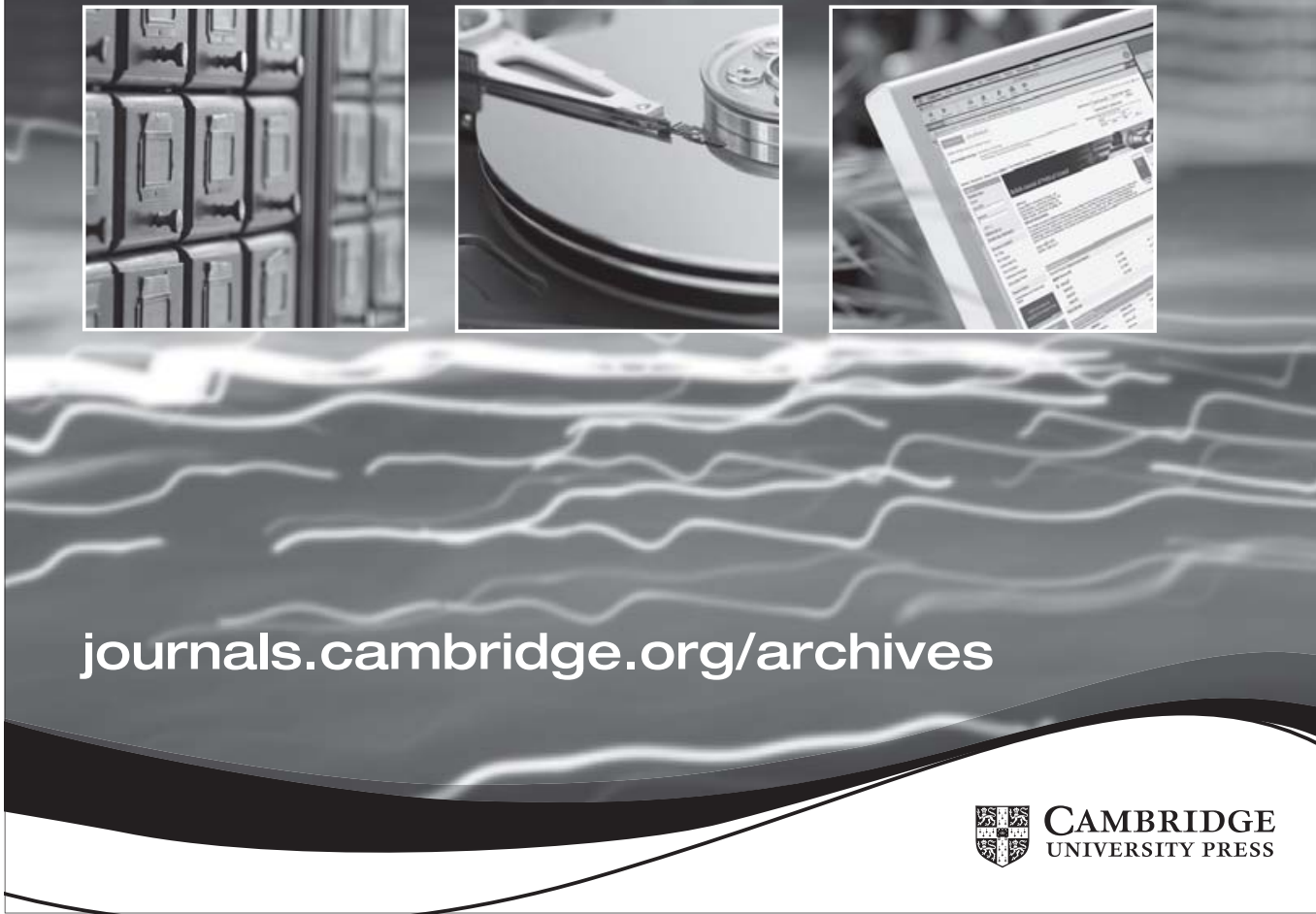